Boston University School of Law

Scholarly Commons at Boston University School of Law

Faculty Scholarship

$10-2010$

\title{
The Law and Economics of Executive Compensation: Theory and Evidence
}

David I. Walker

Boston University School of Law

Follow this and additional works at: https://scholarship.law.bu.edu/faculty_scholarship

Part of the Law and Economics Commons

\section{Recommended Citation}

David I. Walker, The Law and Economics of Executive Compensation: Theory and Evidence, in No. 10-32 Boston University School of Law, Law and Economics Research Paper Series (2010).

Available at: https://scholarship.law.bu.edu/faculty_scholarship/33

This Book Chapter is brought to you for free and open access by Scholarly Commons at Boston University School of Law. It has been accepted for inclusion in Faculty Scholarship by an authorized administrator of Scholarly Commons at Boston University School of Law. For more information, please contact lawlessa@bu.edu. 


\section{BU School of Law}

\section{THE LAW AND ECONOMICS OF EXECUTIVE COMPENSATION: THEORY AND EVIDENCE}

Boston University School of Law Working Paper No. 10-32

(October 6, 2010)

David I. Walker

This paper can be downloaded without charge at:

http://www.bu.edu/law/faculty/scholarship/workingpapers/2010.html 


\title{
The Law and Economics of Executive Compensation: Theory and Evidence
}

\author{
David I. Walker \\ Boston University School of Law \\ Forthcoming, Research Handbook on the Economics of Corporate Law (Claire Hill \& \\ Brett McDonnell, eds.)
}

\section{Introduction}

It is difficult to imagine a corporate law topic that has generated as much consternation, or as much academic research, over the last 20 years as public company executive compensation. In a seminal article on executive pay written in the late 1990s, Kevin Murphy noted that the academic research on the topic "had exploded" (Murphy 1999), but surely the journal pages devoted to the topic in the 1990s is dwarfed by that produced since. The enterprise was and is highly interdisciplinary, with important contributions emanating from law, economics, corporate finance, and accounting, among other fields. This continuing academic interest is not surprising given the level and salience of executive pay and ongoing debate concerning the extent to which pay practices are consonant with corporate or shareholder interests.

This chapter is intended to provide an overview of the theory and evidence regarding public company executive compensation. It is not comprehensive in either the choice of topics or the coverage of those topics, but is meant to provide the reader with an entryway into the literature on a select group of topics. Priority has been afforded to the most central issues in executive pay, to issues that implicate law more or less directly, and to issues that have been the primary focus of research in the last decade.

The chapter is organized as follows. Part II briefly outlines three broad theoretical perspectives on the pay-setting process and the objectives of compensation: the optimal contracting theory, the managerial power theory, and the team production theory. This chapter does not attempt to declare a winner among these theories. Indeed, they are to a large extent complementary. They are useful frameworks to bear in mind, however, as one considers the more detailed theory and evidence that follows.

Part III focuses on the law, theory, and evidence regarding two aspects of executive pay that have generated much of the economic research - the growth in U.S. executive pay and compensation design. Equity compensation is particularly complex, and one goal of this Part is to explain the mechanics and risk and incentive properties of these arrangements.

Part IV considers several areas of regulatory intervention into pay processes board and compensation committee independence, mandatory disclosure, compensation consultants, and shareholder advisory voting on executive pay. The 
focus here is to understand what the theory and evidence tell us about the efficacy and unintended consequences of such intervention. ${ }^{1}$

Part V concludes with some brief thoughts regarding the direction of executive pay regulation and research.

Many interesting topics are omitted from this survey, including some relatively narrow topics, such as "clawbacks" of incentive compensation from executives in the wake of financial restatement. International comparisons are largely neglected, as is consideration of compensation of executives in the financial industry. ${ }^{2}$ The focus instead is on the law and economics of executive pay as it applies to U.S. public companies generally.

As noted, one consideration in prioritizing the material for this survey is the extent to which the topic implicates law. ${ }^{3}$ Therefore, before turning to the theory of executive pay in Part II, a general word regarding the "law" of executive pay is in order.

The law of executive compensation arises from a variety of sources. State corporate law has surprisingly little impact on public company pay arrangements. The Delaware corporate law statute is all but silent on the issue. ${ }^{4}$ Executive pay decisions necessarily implicate officer and director duties of loyalty under corporate law, but while fiduciary duties may constrain pay processes, they do not seriously constrain the amount or form of executive pay (Martin and Thomas 2001, Barris 1992). Similarly, stock exchange listing requirements impose procedural constraints on pay, requiring, for example, shareholder approval of stock option plans. ${ }^{5}$

Historically, governmental regulation of executive compensation consisted largely of SEC disclosure requirements, federal tax rules, and accounting requirements. The influence of these rules on executive pay is discussed in Part III. In the wake of the debacles at Enron, WorldCom, and other firms and the financial crisis of 2007, federal regulatory intervention has increased, but these interventions have been narrowly focused. The Sarbanes-Oxley Act banned loans to executives. Companies participating in financial bailout programs have faced limitations on executive pay overseen by "pay czar" Kenneth Feinberg. Coming soon is mandatory advisory shareholder voting on senior executive pay at all public companies. ${ }^{6}$ Although

\footnotetext{
${ }^{1}$ In aggregate, Parts II - IV consider the role that compensation plays in corporate governance as well as the role that law and governance play in setting compensation.

2 Recent contributions to this emerging literature include Bebchuk and Spamann (2010), Fahlenbrach and Stulz (2010), and Tung and Wang (2010).

${ }^{3}$ Several good surveys are available that focus solely on the economics of executive pay including Murphy (1999), Core et al (2003), and Frydman and Jenter (2010).

${ }^{4}$ DGCL $\S 141(\mathrm{~h})$ simply states as a default rule that "the board of directors shall have the authority to fix the compensation of directors."

5 New York Stock Exchange Listed Company Manual § 303A.08; NASDAQ Manual § 4350(i).

${ }^{6}$ Shareholder "say on pay” is discussed in Part IV.D below.
} 
prompted by specific crises, the increased appetite for federal intervention has been influenced by the theoretical and empirical research on executive pay to which this chapter now turns.

\section{Theoretical Perspectives on the Compensation-Setting Process}

Managerial agency costs lie at the heart of executive compensation theory. Arising from separation of ownership and control (Jensen \& Meckling 1976), these costs reflect the divergence between share value maximizing actions of managers and managers' actual actions, plus the monitoring and bonding expenditures (including contracting costs) undertaken to reduce that divergence. Some degree of agency cost is unavoidable in the modern, widely-held corporation.

Optimal Contracting Theory. The classic economic theory of executive compensation posits that pay arrangements are selected to minimize managerial agency costs and maximize shareholder value (Core et al 2003). Such valueincreasing pay arrangements might result from vigorous bargaining by outside directors attempting to maximize share value or might arise indirectly in response to pressures produced by competitive markets for capital, products, labor or corporate control. Most of the theoretical and empirical literature on executive pay proceeds from the assumption that these arrangements are selected to minimize agency costs and maximize shareholder value.

Managerial Power Theory. Many observed features of executive compensation appear to be inconsistent with a share value optimizing model (Bebchuk et al 2002). An alternative view is based on the idea that executive pay practices do not uniformly reflect vigorous bargaining, and that executives exert more influence over the terms of their pay than would be expected in an arm's length bargaining situation. Under this view, executive pay arrangements reflect agency costs as well as combat them.

Under this managerial power view of the compensation setting process, the threat or reality of investor and financial press outrage play an important role in disciplining compensation. As a result, executives seek out low salience channels of pay and other means of camouflaging their compensation to minimize outrage. The managerial power view of executive pay and the optimal contracting view may co-exist, providing relatively more or less explanatory power at particular firms.

Team Production Theory. A third view is that corporate law issues are better explained as a team production problem rather than a traditional principal-agent problem (Blair \& Stout 1999). Under the team production view, the board of directors serves as a mediating hierarch between stakeholders (executives, employees, creditors) who make firm-specific investments in the company. This theory predicts that compensation arrangements would not be designed to maximize shareholder value, but to balance the interests of the stakeholders. 


\section{Executive Pay Growth and Design - Theory and Evidence}

Historically, sensitivity of pay to firm performance and other aspects of compensation design were the principal focus of the economic literature on executive pay. Recently, attention has turned to explaining the rapid growth in pay. This section explores the theory, evidence, and law on these topics. The totality of the evidence does not support any single theoretical framework regarding executive compensation, although much work remains to be done.

\section{A. Amount and Growth of Executive Pay}

Over the last thirty years, the average compensation of the CEOs of large U.S. public companies has increased in real terms by 500\% (Gabaix and Landier 2006) or more (Frydman and Saks 2008). ${ }^{7}$ The compensation of other senior executives also has risen rapidly, much more rapidly than the compensation of rank and file workers, but has not kept pace with CEO pay (Frydman and Jenter 2010).

No positive law directly affects the level of executive compensation in the U.S. Disclosure requirements and mandatory shareholder advisory voting on executive pay, which are discussed below, may have an indirect impact on the amount of pay. IRC $\S 162(\mathrm{~m})$, which limits the deductibility of certain senior executive pay to $\$ 1$ million per executive per year, might be thought to have a more direct effect on executive pay, but given an exception allowing unlimited amounts of deductible "performance-based" compensation, $\S 162(\mathrm{~m})$ likely has more impact on the design than the amount of executive pay.

Analysts have struggled to explain the rapid growth in U.S. CEO pay. Equity compensation, which did not become significant until the 1980s, accounts for almost all of the growth (Frydman and Jenter 2010). Holmstrom and Kaplan (2001, 2003) argue that the addition of this risky pay necessitated an overall increase in compensation of risk averse executives. ${ }^{8}$ Taking the managerial power view, Bebchuk and Grinstein (2005) suggest that the bull market of the 1990s weakened the outrage constraint, allowing boards to increase executive pay, and that the design of equity compensation reduced the salience of this pay, permitting transfers of value that would be inconceivable if paid in cash. In a similar vein, Murphy (2003) and Jensen, Murphy, and Wruck (2004) argue that the favorable accounting treatment of options in

${ }^{7}$ According to a recent report, the median total direct compensation of CEOs of 200 large U.S. public companies was \$6.95 million in 2009 (Wall Street Journal/Hay Group 2010). Median salary was \$1 million; median annual bonus was \$1.5 million; median value of long-term incentives was over \$5 million. Although perquisites continue to attract press coverage, they are now fairly trivial economically, with a median value granted in 2009 of $\$ 144,000$. Not included in total direct compensation was a median increase in value of executive pensions of \$1.3 million. The components of executive pay are discussed in more detail in Part III.B.1.

8 This view is in line with Jensen and Murphy (1990a) who had argued that improving executive incentives would necessitate paying executives more. 
the 1990s led boards to systematically undervalue and over-issue this form of compensation.

Frydman (2007) and Murphy and Zabojnik (2004, 2007) explain the growth in CEO pay as following from a shift in the requisite skill set. Formerly, firm-specific skills dominated, limiting outside opportunities, but increasingly general management skills dominate, which leads to greater competition for talent and to managers capturing greater rents. Recently, Gabaix and Landier (2006) have proposed a model involving competitive matching of CEO talent and firms. The model predicts that average compensation should move with firm size, and the model explains the increase in pay over time, as well as cross-industry and cross-country pay observations. ${ }^{9}$ The authors find very little dispersion in CEO talent at the largest firms, but given the tremendous amount of assets under management and a multiplier effect, the model can explain large pay differentials. The idea that small differences in talent are consistent with large differences in pay was also explored by Himmelberg and Hubbard (2000).

\section{B. Compensation Design ${ }^{10}$}

Broadly speaking, executive pay provides both compensation and incentives. In order to attract and retain effective managers, companies must provide a competitive package in terms of both amount of pay and type of pay. Given the difficulty of directly monitoring the executives, however, the incentives created by executive pay are extremely important in mitigating agency costs. Of course, pay is not the sole source of incentives within the executive suite. The risk of firing and loss of reputation also influence managerial performance, and some executives, often company founders, hold so much company equity that annual pay incentives can be dispensed with, but for most executives pay design plays an important role in creating incentives.

These goals create a tradeoff. On the one hand, directors want to provide highpowered incentives to encourage executives to work hard and to take on risky projects. $^{11}$ On the other hand, pay packages have to be mutually acceptable, and nondiversified executives apply large discounts to risky, high powered incentive arrangements, creating a gap between their cost to shareholders and their value to the executives (Hall and Murphy 2002, Core et al 2003).

${ }^{9}$ Bebchuk and Grinstein (2005) analyzed increases in executive pay over a shorter period (1993-2003) and found that the growth in pay could not be explained by changes in firm size, performance, and industry mix.

${ }^{10}$ This section draws heavily from Walker (2010).

${ }^{11}$ All else being equal, executives and other employees whose financial and human capital generally is over-invested in their companies tend to disfavor risky projects relative to diversified shareholders (Hall 2003). 
A voluminous theoretical and empirical literature explores these design issues, most of it adopting an optimal contracting perspective. ${ }^{12}$ This section will briefly and selectively explore this literature and highlight current issues and puzzles.

\section{Compensation Elements}

Public company executive pay is comprised of the following elements: annual salary, short-term bonus opportunities, long-term incentives including equity compensation, pension contributions and earnings, and perquisites. The design of each element is remarkably uniform. As discussed below, tax and accounting rules contribute to this uniformity. Nonetheless, even given uniform building blocks, firms can create compensation packages that vary widely in their incentive and risk properties.

Although each element of executive pay plays a role within the optimal contracting theory, equity compensation (stock and options) has been the particular focus of much of the theoretical and empirical research in this area. There are two reasons for this. First, equity compensation accounts for well over half of the aggregate ex ante value of executive pay at large public companies. Second, equity compensation is viewed as particularly important in aligning managerial and shareholder incentives.

Both restricted stock and options tie pay to stock price performance. Restricted stock does so in a linear fashion. Paradigmatically, restricted stock is granted to an executive at no explicit cost, but the stock cannot be sold or otherwise transferred until it "vests" in a certain number of years. If the executive's employment terminates prior to vesting, the stock typically must be returned. Assuming that the stock will ultimately vest, in the interim, the value of this restricted stock moves dollar for dollar with the firm's share price. ${ }^{13}$

Options provide the holder with a right, but no obligation, to purchase shares of stock at a pre-determined exercise price. ${ }^{14}$ Thus, the defining feature of an option is that the payoff is based on the positive difference, if any, between the share price at exercise or settlement and the exercise price of the instrument. If the share price on a potential exercise date fails to exceed the exercise price, the option provides zero payout. Compensatory stock options typically are granted with an exercise price equal

${ }^{12}$ For more exhaustive discussion of executive pay design issues and the economic literature on this topic, the reader should see Murphy (1999), Core et al (2003), Frydman and Jenter (2010).

${ }^{13}$ Some firms predicate vesting of restricted stock on satisfaction of performance criteria as well as the passage of time, and some firms utilize "performance share” plans that are the non-equity, economic equivalent of performance vested restricted stock. However, each of these instruments links pay to stock price performance in a linear fashion.

14 The exercise price of employee stock options is almost always a fixed price specified at grant, and almost always equal to the fair market value of the stock at grant. A few firms have experimented with indexing exercise prices to a basket of competing stocks or to a broad measure of the stock market, such as the S\&P 500, with the idea of focusing the option payout on firm-specific performance rather than market movements generally (Rappaport 1999). 
to the market price of the underlying stock on the date of the grant, and like restricted stock, options typically vest and become exercisable several years following grant.

The value of an option increases and decreases with the value of the underlying shares, but the relationship is not linear, it is convex. ${ }^{15}$ An option that is far out of the money, i.e., with exercise price far in excess of the value of the underlying shares, has a very low value and a value that is relatively insensitive to small changes in the price of the underlying shares. The value of an option that is far in the money, i.e., with exercise price far below the value of the underlying shares, approaches the current share price less the exercise price, and that value moves dollar for dollar with small changes in the price of the underlying shares.

The sensitivity of an option's value to small changes in the underlying share price is known as the option's delta, and delta is simply the slope of the curve that plots the value of the option against the value of the underlying stock. ${ }^{16}$ Compared with a share of restricted stock, an at-the-money option on a single share of stock is both less expensive to grant and less sensitive to share price movement. However, per dollar of compensation expense, options produce more high powered incentives than restricted stock. For example, an at-the-money option on a single share of stock might have a value that is $40 \%$ of the value of a share of restricted stock, but a delta that is $75 \%$ of the delta of a share of restricted stock, yielding almost twice the sensitivity to share price per dollar of compensation expense. ${ }^{17}$

At the time of the grant, the sensitivity of option value to stock price depends on the exercise price of the option. Although restricted stock and options are often discussed as separate categories, economically, they are different in degree, not in kind. Economists view restricted stock as a zero exercise price option, an option with zero convexity.

In addition to increasing the sensitivity of pay to share price performance, adding options to compensation packages increases the sensitivity of pay to the volatility of share prices. Economists use the term "vega" to denote the sensitivity of option value to share price volatility. The value of shares is not directly affected by increases or decreases in volatility, and thus stock has vega of zero. However, the value of an option increases with increasing volatility, and thus options have positive vega. The sensitivity of pay to stock price volatility is important in assessing the effect of compensation design on the willingness of executives to take on risky projects.

\section{Impact of Tax and Accounting Rules on Compensation Design}

\footnotetext{
${ }^{15}$ When graphed, a convex relationship presents a "u" shaped curve. The relationship between option value and the price of the underlying shares tracks the right half of the " $u$ ".

${ }^{16}$ For example, an option delta of .75 means that when the price of the underlying shares changes by a small amount, the value of the option changes by $75 \%$ of that amount.

${ }^{17}$ Per dollar of compensation expense, the option would have a delta that was 1.9 times $(.75 / .4)$ the delta of the stock.
} 
As noted, there is little direct regulation of executive pay design. Some potential compensation devices, such as insider trading and executive loans, are precluded under federal law. Mandatory disclosure and shareholder "say on pay" may influence design, and are given separate treatment below. This subsection will consider the substantial influence of tax and accounting rules on the design of executive pay packages.

\section{a. Accounting Rules}

Through 2005, U.S. financial accounting rules favored conventional nondiscounted options over other forms of equity pay. Under the accounting standard in force at the time, companies were required to recognize as compensation expense the grant date intrinsic value of stock or options issued to employees. ${ }^{18}$ (The intrinsic value of an option, also known as the option spread, is the positive difference, if any, between the value of the underlying stock and the option exercise price.) The expense was accrued ratably over the vesting period of the instrument, and at that point the accounting books were closed. There was no requirement to update the expense for an option grant as its intrinsic value fluctuated over time. As a result, no expense was recorded at any point for options with a fixed exercise price issued at or out of the money, because, by definition, these options had zero intrinsic value on the date of grant. By contrast, restricted stock grants resulted in an accounting expense equal to the full fair market value of the underlying stock at grant (less any amount paid for the stock), despite the restrictions on transfer. Discounted or in-the-money options resulted in an accounting expense equal to the "spread" at grant. The accounting treatment of options carrying an indexed exercise price was even more complicated. These options generally resulted in a charge against earnings, and the charge had to be updated on a regular basis until the exercise price ultimately was fixed.

In 2004, the Financial Accounting Standards Board (FASB) issued a new standard requiring firms to determine the grant date fair value of all equity compensation and to recognize the expense over the vesting period of the stock or option. ${ }^{19}$ For option compensation, this rule requires firms to calculate a grant date value using an option pricing model. The new standard largely eliminates the previous accounting-induced distortions between stock and option compensation, between discounted and nondiscounted options, and between conventional fixed exercise price options and options with exercise prices linked to a market index. ${ }^{20}$

The accounting treatment of options has no affect on cash flows, but Murphy (2003) argues that the perception that options represented inexpensive compensation under the prior accounting regime contributed to the dramatic increase in their use in

\footnotetext{
${ }^{18}$ The applicable rule was Accounting Principles Board, Opinion No. 25, Accounting for Stock Issued to Employees (1972).

${ }^{19}$ FASB, Statement of Financial Accounting Standards No. 123 (revised 2004).

${ }^{20}$ Some potential for distortion remains. The fair value of an option is determined using the BSM or binomial model and is manipulable. Thus, options provide some accounting flexibility that stock compensation does not. Walker and Fleischer (2009) discuss the potential for option expense manipulation.
} 
the 1990s. Option use has declined in the wake of the FASB's rationalization of equity compensation accounting. Option grants accounted for $60 \%$ of the ex ante value of S\&P 500 senior executive compensation in aggregate in 2000. By 2008, the aggregate contribution had declined to about 25\%, largely through the substitution of restricted stock and economic equivalents for options (Walker 2010). Although a number of factors may have contributed to substitution of restricted stock for options, Brown and Lee (2007) and Carter, Lynch, and Tuna (2007) provide evidence that the shift in emphasis in equity compensation plans relates, at least in part, to FASB's mandate that firms expense stock option compensation.

\section{b. Tax Rules}

Several tax rules have had significant influence on executive compensation design. IRC $\S 162(\mathrm{~m})$, enacted in 1993, limits the deductibility of non-performance based compensation issued to certain senior executives to $\$ 1$ million per year. Although firms increasingly treat the $\$ 1$ million “cap” as simply one consideration, and not a limitation on non-performance based pay, the enactment of $\S 162(\mathrm{~m})$ likely contributed to the shift to option compensation in the 1990s (Hall and Liebman 2000, Polsky 2007).

Current U.S. tax rules essentially limit the equity compensation menu to restricted stock (and economically similar instruments such as performance shares) and nondiscounted, fixed exercise price stock options (Walker 2009). IRC § 409A all but precludes firms from issuing explicitly discounted stock options, i.e., options with exercise prices less than the fair market value of the underlying stock at grant, or indexed options. Under regular U.S. tax rules, compensation arising from a nondiscounted option is not taxed until the option is exercised, ${ }^{21}$ but under IRC $\S 409 \mathrm{~A}$, enacted in 2004, compensation income arising from a discounted or indexed option would be taxed at vesting, rather than at exercise, and would be subjected to an additional $20 \%$ penalty tax.

Compensating executives with restricted stock or non-qualified stock options creates a modest global (i.e., employer plus employee) tax advantage in comparison to a cash compensation alternative (Walker 2004, Knoll 2004). The advantage arises from the deferral of taxation until the stock vests or the options are exercised. However, the advantage of deferring gains is to some extent offset by the disadvantage of deferring losses in situations in which the equity falls in value. The extent of the ex ante tax advantage depends on, inter alia, the impact of capital loss limitations (Walker 2004, Yale 2009).

\section{Theoretical and Empirical Evidence on Compensation Design}

${ }^{21}$ The discussion in this and the following paragraph assumes that options are non-qualified options, i.e., are not incentive stock options (ISOs) as defined in IRC $\S 422$. The tax rules applying to ISOs differ, but ISOs account for an economically trivial portion of executive equity compensation (Hall and Liebman 2000). 


\section{a. Pay for Performance Sensitivity (Delta)}

Much of the early empirical work on executive compensation design focused on the sensitivity of executive wealth to changes in shareholder value. The incentive effects of existing equity holdings often swamp those created by current year compensation (Core et al 2003). Thus, both must be considered in analyzing sensitivity of pay to performance. Jensen and Murphy (1990b) reported that between 1974 and 1986 the median CEO of 1300 companies included in a Forbes' survey experienced a change in wealth of $\$ 3.25$ for each $\$ 1000$ change in shareholder value. The bulk of this sensitivity reflected the delta of executive stockholdings. The remainder reflected option delta as well as the authors' calculation of the increased risk of dismissal associated with a decrease in shareholder wealth. Although the results were statistically significant, Jensen and Murphy concluded that the link between pay and performance was insufficient to constrain executives from, for example, consuming excessive perquisites.

Other commentators noted that even the relatively small delta found by Jensen and Murphy might be adequate to align managerial and shareholder incentives with respect to certain decisions such as the decision to resist a hostile takeover, since the absolute value of the executives' incentives would be more important than the fraction of the firm "owned" by the executives (Hall and Liebman 2000, Baker and Hall 2004). ${ }^{22}$ Moreover, Jensen and Murphy's data reflected the state of executive pay existing prior to the stock option boom of the 1990s. Even as firms continued to grow, pay for performance sensitivity increased in the 1990s and 2000s as executive stock and option holdings multiplied. Hall and Liebman (1998) reported that the Jensen and Murphy statistic doubled by 1994 and quadrupled on a size-adjusted basis.

Brick, Palmon, and Wald (2010) find that average pay for performance sensitivity for CEOs included in Standard and Poor's ExecuComp database doubled between 1992-1994 and 2002-2004. In fact, Brick, Palmon, and Wald suggest that some executives may be bearing too much firm-specific risk. They find that greater pay for performance sensitivity is related to lower future stock returns, which could reflect, in part, flight from risk.

Other agency cost explanations have been put forward to explain observed pay-forperformance sensitivities that are lower than expected at first blush. Reduced delta may mitigate executive incentives to maintain inefficiently high levels of investment (Benmelech et al 2010) or mitigate executive incentives to manipulate stock prices (Peng and Roell 2008, Goldman and Slezak 2006). Under the team production theory, pay-for-performance sensitivity that is less than optimal from the perspective of maximizing shareholder value could be an appropriate accommodation to more risk averse corporate constituents, such as creditors and employees.

${ }^{22}$ The idea is that in deciding whether to take a perk, an executive would consider the fraction of the cost that she would bear directly, whereas in deciding whether to oppose a hostile takeover, she would consider the magnitude of the payout she would receive on exit. 


\section{b. Equity Portfolio Convexity}

Since 2004 there has been no significant regulatory bias favoring stock options or restricted stock, and we have observed greater variety from firm to firm in the mix of equity compensation granted to executives (Walker 2010). How is the equity mix determined?

Under an optimal contracting model, the efficient mix, or convexity, of equity compensation would depend on employee, firm, and market characteristics. At the firm level, theoretical models suggest that greater growth opportunities should result in more option-heavy or convex executive pay contracts that increase the incentives to exploit those opportunities (Core and Qian 2001). To some extent, as growth opportunities increase, the benefit of encouraging executives to take on risk and maximize firm value more than offsets the discount the executives apply to risky compensation. In the same vein, optimal convexity increases with the desired riskiness of projects (Choe 2001, Choe 2003), but decreases with firm risk generally and with firm leverage, which increases the risk of an option contract (Choe 2003). The overall market environment affects optimal convexity in a similar fashion, i.e., market volatility should be negatively correlated with convexity (Lambert and Larcker 2004). Finally, optimal convexity increases with the marginal productivity of executive effort at the firm (Lambert and Larcker 2004).

Of the employee characteristics modeled by corporate finance researchers, risk aversion appears to be the most important, and certainly the most frequently modeled, individual trait affecting optimal sensitivity (Hall and Murphy 2000, Tian 2004, Tian 2001, Lambert and Larcker 2004, Dittmann and Maug 2007, Feltham and Wu 2001). ${ }^{23}$ A highly risk averse executive will more greatly discount options with more remote payoff prospects. Thus, as risk aversion increases, the optimal design shifts in the direction of stock (Tian 2001, Hall 2003).

Depending on firm and employee characteristics (and on model specifications), researchers have concluded that optimal equity compensation design ranges from far in-the-money options (i.e., restricted stock) (Hall and Murphy 2002, Dittmann and Maug 2007) to at-the-money options (Dittmann and Yu 2009) ${ }^{24}$ to far out-of-themoney options (Lambert and Larcker 2004). Optimal equity compensation design is quite sensitive to model specification, but even within a given model, optimal sensitivity can be highly dependent on the assumptions listed above. Tian (2001) finds that at-the-money options are nearly optimal for executives who exhibit relatively low risk aversion; in-the-money options are optimal for those with somewhat greater risk aversion; and for executives who are highly risk averse, restricted stock is optimal.

23 Other characteristics that have been modeled include loss aversion (Dodonova and Khoroshilov 2006), effort aversion (Palmon et al 2008, Tian 2001, Dittmann and Maug 2007, Feltham and Wu 2001), overall wealth (Tian 2001), firm equity held (Tian 2001), and outside investment opportunities (Tian 2001).

${ }^{24}$ Dittmann and Yu's model indicates that most options should be granted in the money but that the incremental benefit is less than the tax cost of granting in-the-money options. 


\section{c. Cross-sectional Variation}

Some of the foregoing theoretical predictions are supported by cross-sectional data. Core and Guay (1999) find that firms actively manage the level of new CEO equity incentives in response to deviations between existing incentives and optimal incentives associated with economic determinants such as firm size, growth opportunities, and monitoring costs. Quay (1999) finds a positive association between the sensitivity of CEO wealth to firm risk and investment opportunities.

On the other hand, a great deal of uniformity in equity pay design persists even after the relaxation of accounting rules favoring option compensation. Walker (2010) demonstrates that the mix of stock and options granted to senior executives in the late 2000's is not uniformly or normally distributed from firm to firm but is clustered, with most firms granting options only, stock only, or a 50/50 mix by ex ante value. He also finds that the mix of stock and options tends to be consistent within executive suites, casting doubt on the extent to which firms adjust equity mix to optimize incentives.

\section{Compensation Design Puzzles for the Optimal Contracting Model}

\section{a. Relative Performance Evaluation}

According to theoretical predictions (Holmstrom 1982), executive compensation arrangements should employ relative performance measures in order to filter out the noise of industry or market movements over which executives have no control. Instead of basing an annual bonus on total shareholder return, for example, a firm could base the bonus on the return relative to the average return of a peer group of companies. In practice, relative performance evaluation is rarely observed (Core et al 2003).

The value of equity compensation is particularly sensitive to market movements over which executives have no control. Rappaport (1999) and others have proposed that the exercise price of options be indexed to filter out market swings, but indexed options have been used by only a handful of companies. Unfavorable accounting treatment might account for the dearth of indexed options before 2004, and current tax rules would complicate their use today. However, these rules do not explain the failure of firms to condition restricted stock vesting or performance share awards on relative firm performance. However, as Core et al (2003) explain, the lack of explicit relative performance evaluation in executive pay arrangements does not mean that executives do not adjust their own portfolios in order to manage their exposure to the broader market. $^{25}$

\section{b. Stock Option Backdating}

${ }^{25}$ A related puzzling strand of research suggests that executives often are rewarded for good luck - felicitous occurrences outside their control - but are not penalized for bad luck (Bertrand and Mullainathan 2001, Garvey and Milbourn 2006). 
In March 2006, the Wall Street Journal offered evidence suggesting highly suspicious timing and pricing of stock options issued by some companies in the late 1990s and early 2000s (Forelle and Bandler 2006). Almost all options are issued with an exercise price equal to the fair market value of the company's stock on the date of the grant. The evidence indicated that the grant dates of some stock options had been selected with hindsight. By "backdating" option grants to low stock price dates, these firms had effectively granted options that were "in the money" from the start.

Further research revealed that the practice of backdating was quite widespread. Heron and Lie (2009) estimated that about 30\% of firms participated in backdating during this period. Bebchuk et al (2009) found that 9\% of CEO options granted between 1996 and 2005 were manipulated to achieve exercise prices equal to one of the three lowest prices of the month.

Although stock option backdating was not in itself illegal, firms that backdated options ran afoul of both accounting and tax rules (Walker 2007). Numerous firms were required to restate their financials to properly account for the backdated options. The SEC investigated option grant practices at over one hundred companies and filed civil and/or criminal charges against executives of a handful of firms.

The backdating episode remains something of a mystery. The reputational and financial cost to firms and executives that engaged in the practice and were discovered was great, and the payoff to the recipients of backdated options was often less than one might expect. Efficiency explanations for backdating are unpersuasive. In some cases, backdating may have been inadvertent or, though purposeful, an innocent mistake (Fleischer 2007). In many cases, however, backdating yielded stealth compensation, which calls into question the capacity or motivation of boards to oversee executive compensation.

\section{Regulatory Intervention and Executive Pay - Selected Topics}

This Part considers four aspects of the executive compensation process in which regulatory intervention has occurred or is in the offing - board and compensation committee independence, disclosure, use of compensation consultants, and shareholder "say on pay." These topics have in themselves generated considerable research. This Part considers that research and what it tells us about the efficacy and unintended consequences of such intervention.

\section{A. Impact of Board Structure on Executive Pay}

There is a widespread view that board of director independence should lead to improved corporate governance, including more responsible executive pay practices. Public company boards and compensation committees, which are principally responsible for determining senior executive pay, have become more independent over the last 20 years in response to various regulatory initiatives. 
Since 1993, companies that seek to take advantage of the performance-based-pay exception to the limit on the deductibility of senior executive pay under IRC $\S 162(\mathrm{~m})$ have been required to limit compensation committee membership to "outside" directors, i.e., directors who are not and have not been employees or executives of the company. Stock exchange rules adopted in 2003 require listed companies to have compensation committees composed entirely of "independent" directors, i.e., directors with no material ties to the listed company aside from their compensation as directors. Stock exchange rules also require that a majority of board members be independent directors. Complete compensation committee independence was federally mandated under the Dodd-Frank Act.

The evidence regarding the relationship between board or compensation committee independence and the quality of executive pay is mixed (O’Reilly and Main 2005). For example, Core et al (1999) find a positive association between CEO pay and the fraction of outside directors on the board appointed by the CEO. They also find a positive association between outside directors who serve on multiple boards, and presumably have their attention more divided, and CEO pay. On the other hand, Anderson and Bizjak (2003) find little evidence that greater compensation committee independence affects executive compensation.

There are reasons to be both more and less optimistic about the ability of high quality boards and compensation committees to effectively manage executive pay than these studies suggest. While most studies have focused on the amount of executive pay or pay for performance sensitivity, Sun et al (2009) examine the relationship between compensation committee quality and the quality of equity grants. They find that options issued to executives by firms with higher quality compensation committees generate greater future operating income.

On the other hand, Singh (2006) provides a theoretical model that undermines the simplistic view that entrusting executive compensation to more independent directors is necessarily in the interest of shareholders. He employs a signaling model to demonstrate that independent directors with career concerns might provide pay packages with inefficiently high incentives if such incentives are generally associated with good governance.

Other research questions the extent to which we should rely on nominally independent directors to effectively manage executive compensation. In a series of papers, Main, O’Reilly, and Wade have stressed the importance of social and psychological forces on boards. As in any example of small group decision making, these authors argue that a norm of reciprocity and social influence affect outcomes. Nominally independent directors may feel beholden to the CEO even if that individual is not a member of the nominating committee that appointed them to the board. Independent directors who are demographically similar to their CEOs tend to award their CEOs greater compensation (Main, O’Reilly, and Wade 1995). 
Moreover, while stock exchange rules and legislative proposals focus on first order relationships between companies and board members, Larcker, Richardson, Seary, and Tuna (2005) demonstrate that more attenuated connections between inside and outside directors can affect executive pay. They calculate the distance, à la Six Degrees of Separation, between each member of the boards of over 3000 firms, ignoring, of course, the link created by serving on the same board. They find that a relatively short "backdoor" distance between the CEO and the members of the compensation committee and between inside and outside directors is associated with greater CEO pay.

A related structural issue is whether the CEO also serves as board chairman. Splitting these roles is common abroad and is becoming more common in the U.S. $36 \%$ of S\&P 500 companies split the CEO and Chairmen roles in 2009, up from $22 \%$ in 2002 (Millstein 2009). As in the case of outside director independence, some researchers have found a positive relationship between CEO pay and CEO/Chairman “duality" (O'Reilly and Main 2007). Earlier studies are cited in O'Reilly and Main (2005).

In sum, support for the intuition that increased board and compensation committee independence leads to more shareholder-friendly executive pay practices is mixed, at best. In fact, some observers question whether the premise is well founded to begin with. As Holmstrom (2008) and Core et al (2005) observe, outside directors serve other important roles in addition to policing executive pay. Their primary value may lie in advising management on strategic decisions and in succession planning. The individuals who would best perform these roles and the attitudes and processes they would adopt vis-a-vis management in doing so might be different than the individuals and policies adopted by executive pay cops. In other words, the optimal board membership and processes would maximize share value, but would not necessarily minimize managerial agency costs.

\section{B. Compensation Disclosure}

Mandatory periodic disclosure of executive pay dates back to the Securities Exchange Act of 1934. Two efficiency explanations for mandatory disclosure might apply particularly to executive compensation. Easterbrook and Fischel (1984) argue that voluntary production of information would be suboptimal from a social perspective in cases in which the disclosure creates a positive externality. Bizjak, Lemmon, and Naveen (2008) document that benchmarking of compensation against peer firm pay is pervasive and argue that benchmarking is an efficient means of determining the reservation wage. Of course, if all firms engage in benchmarking, each would have a private incentive to disclose compensation data, at least to compensation consultants who effectively manage the benchmarking process. Thus, the more important rationale for mandatory disclosure of executive compensation is the existence of managerial agency costs (Coffee 1984, Mahoney 1995). Investors rely on mandatory disclosure to monitor managerial self-dealing, including executive compensation. 
Given the agency problem, it is important that the mandatory disclosure regime be both comprehensive and transparent. The current SEC disclosure regime largely achieves these objectives. Prior regimes did not and likely led to distortions in pay practices as companies sought to minimize the apparent compensation of executives.

The "modern" disclosure regime dates from 1992 when the SEC reinstituted tabular disclosure of executive pay and expanded coverage to the CEO plus the four most highly compensated executives other than the CEO. The 1992 disclosure regime required a summary compensation table that detailed the dollar value of salary, annual bonuses, restricted stock awards, payouts from non-equity long-term performance plans, and perks, as well as the number of shares underlying option grants.

Although an improvement over the immediately preceding disclosure regime, the 1992 rules were less than ideal. The summary compensation table did not yield a bottom line dollar value of pay. Some items were included on an ex ante basis; others on an ex post basis; other items were excluded from the summary table entirely. In addition to stock option value, the value of defined-benefit pension plans was not included in the summary compensation table and pension values have been found to represent a significant fraction of remuneration for CEOs who participate in such plans (Bebchuk and Jackson 2005).

Under the 1992 regime, companies were required to disclose further information on stock option grants in a separate table and were given the choice of reporting the Black Scholes value of these options or the "potential realizable value" based on arbitrary assumptions of 5\% and 10\% annual appreciation in the stock price during the option term. Murphy (1996) provides evidence that firms exploited this choice of methodology to reduce reported compensation.

The lack of comprehensiveness in the disclosure regime raised two concerns. First, investors might not have received an accurate picture of executive pay. Bebchuk and Jackson (2005) suggest that the poorly disclosed defined-benefit pension entitlements led to overestimation of the sensitivity of executive pay to performance. Second, firms may elect to compensate executives through channels that are less transparent, even if less efficient (Bebchuk et al 2002). Anecdotal evidence indicates that a lack of transparency encouraged some directors to approve enhancements to executive defined-benefit pensions (Bebchuk and Jackson 2005).

Executive compensation disclosure was improved significantly in 2006. The summary compensation table was revised to provide a bottom line figure for total ex ante compensation including the annual increase in value of defined-benefit pensions. The 2006 rule also eliminated firm choice regarding option valuation. Firms were required to report the amount expensed under GAAP for stock and options in the summary table. The amount expensed under GAAP is the "fair value" (essentially the Black-Scholes value) of options pro-rated over the option vesting period. The inclusion in the summary table of pro-rated accounting expense for equity 
compensation, however, was inconsistent with the goal of providing a bottom line figure for the value of pay provided to an executive within the fiscal year. This deficiency was corrected in 2009. Going forward, firms are required to report the total ex ante value of stock and option grants in the year of grant, yielding a reasonably accurate and comparable total compensation figure in the summary table.

Earnings statements prepared in accordance with GAAP are an additional source of compensation disclosure. Although these statements do not focus specifically on senior executives, they do provide an overall tally of compensation expense within the firm. As noted above, stock option compensation was elevated from a footnoted item to a recognized expense in 2004, largely eliminating an accounting bias in favor of options.

Given reasonable accurate and comprehensive compensation disclosure in earnings statements and proxy statements, are there remaining disclosure concerns? Some commentators have suggested enhanced disclosure combined with the ubiquitous practice of benchmarking pay versus that of peer firms leads to upward ratcheting of compensation (Bebchuk et al 2002). Bizjak, Lemmon, and Naveen (2008) find that the "vast majority" of firms that benchmark target pay levels at or above the $50^{\text {th }}$ percentile. Grinstein, Weinbaum, and Yehuda (2010) find that following enhanced disclosure requirements for executive perks in 2006, firms that had granted low levels of perks relative to their peers increased perks, while firms that granted relatively high amounts of perks did not decrease them. Upward ratcheting may result from boards' genuine beliefs that their executives are above average or from an unwillingness to risk undermining investor confidence by admitting, through compensation policy, that management is below average (Elson 2003).

Finally, given the complexity of executive compensation, it is unrealistic to think that no undisclosed benefits are flowing to executives. Firms that backdated stock options in order to reduce exercise prices reported values for these options that were far less than the true fair values of these instruments (Walker 2007). Even without backdating, the ability of executives to exploit information advantages in timing grants and exercises of equity compensation causes the actual expected value of equity pay to exceed that reported to shareholders.

\section{Compensation Consultants}

Eighty-six percent of S\&P 1500 firms utilized compensation consultants in 2006 (Cadman, Carter, and Hillegeist 2010). Consultants can increase the efficiency of compensation processes by providing expert advice on the economic, disclosure, tax, and accounting consequences of very complex pay arrangements and by acting as information intermediaries - collecting confidential pay data and providing summarized, redacted data to their clients. However, many observers question whether consultants serve the interests of investors or the managers who have traditionally hired them. Objectivity is particularly suspect in situations in which the 
compensation consultant provides other services, such as actuarial or benefits management services, to the company that engages them for compensation consulting.

Historically, there has been no regulation of the relationship between pay consultants and public companies in the U.S. In fact, disclosure of the use of compensation consultants was not mandated until 2006. However, the Dodd-Frank Act of 2010 confers upon compensation committees the authority to hire and manage compensation consultants. The act also addresses compensation consultant conflicts of interest, requiring consultants to meet standards of independence established by the SEC.

Do compensation consultants, particularly conflicted consultants, favor management? The evidence, as summarized and augmented in Conyon (2010), is mixed. Some studies have found a positive correlation between the use of compensation consultants and CEO pay, but CEOs of firms utilizing consultants tend to receive pay packages with a greater emphasis on equity. Hence, the correlation found could represent a risk premium (Conyon 2010). Similarly, Walker (2010) reports that firms that do not use compensation consultants tend to grant pay packages with fewer equity compensation elements. But again, the direction of causation is unclear. It may be that consultants complicate pay packages to justify their services or it may be that firms at which complex pay arrangements are optimal are more likely to employ the services of consultants.

Murphy and Sandino (2009) find an association between conflicted consultants and greater CEO pay. ${ }^{26}$ However, Cadman, Carter, and Hillegeist (2010) and Conyon, Peck, and Sadler (2009) find little or no evidence that consultant conflicts lead to greater CEO pay. Additional evidence provided in Conyon (2010) casts further doubt on the theory that the use of consultants, conflicted or otherwise, leads to greater executive pay.

\section{Shareholder "Say on Pay"}

The Dodd-Frank Act of 2010 mandates non-binding shareholder voting on executive pay. Over fifty U.S. companies voluntarily adopted shareholder "say on pay" prior to this legislative mandate, and a majority of shareholders voted to disapprove of pay plans at Motorola, Occidental Petroleum, and KeyCorp in 2010. Although the vote is precatory, executives will not want to lose shareholder votes on pay and will likely modify pay practices as needed to gain majority approval. The question is whether the effect of "say on pay" on executive compensation will be salutary.

Although "say on pay" is new in the U.S., it has been mandated for U.K. public companies since 2002. The evidence regarding the U.K. experience is mixed. Alissa (2009) found a relationship between U.K. shareholder dissatisfaction, as measured by

${ }^{26}$ Surprisingly, the authors find that CEO pay is higher when compensation consultants are employed by the board rather than management. 
the percent of no votes cast, and greater than expected CEO pay. ${ }^{27}$ Ferri and Maber (2009) found no evidence of a change in the level or growth rate of CEO pay after the introduction of "say on pay" in the U.K. They did find a change in compensation design. A significant number of firms increased the sensitivity of pay to poor performance by curtailing highly publicized "rewards for failure," such as generous severance contracts. The authors found that firms made these changes before shareholder votes as well as after, suggesting that the threat of an adverse vote had an effect on compensation. It is also clear that U.K. firms have increased consultation with institutional shareholders regarding pay practices.

From a theoretical standpoint, Gordon (2009) argues that mandatory "say on pay" is likely to inefficiently restrict diversity in pay practices. He suggests that proxy advisory firms, which are already influential in corporate elections, would become more influential under mandatory "say on pay," and that these firms will reduce search costs by establishing "close to 'one size fits all'” best practice guidelines. Motorola, which suffered a negative shareholder vote on executive pay, has an unusual management structure with co-CEO's, who are highly compensated, but whose compensation is closely linked to performance and to the firm's strategy of splitting into two publicly traded companies. For good or ill, such a strategy might be harder to maintain under mandatory "say on pay."

\section{Executive Pay Regulation and Research: Going Forward}

Where are executive pay regulation and research headed? This chapter concludes with brief thoughts on the first question and a suggestion regarding the second.

It appears that mandatory shareholder "say on pay" will be the most significant, perhaps the only significant, generally applicable executive pay reform to come out of the most recent financial crisis. Other reforms certainly have been advanced. Commentators who blamed the crisis on reckless, short-term behavior by executives whose compensation was inadequately linked to long-term firm performance proposed the elimination of options and/or the imposition of lengthy holding periods on stock grants (Samuelson and Stout 2009, Bhagat and Romano 2009, Posner 2009). The opposing view is that executive compensation is a highly complex subject that is not well suited for one-size-fits-all, coercive regulation (Gordon 2009, Walker 2010b). Going forward, U.S. public companies will likely face a combination of evolving disclosure and board/committee independence requirements, further congressional hearings, and perhaps some industry-specific (e.g., banking) regulation. Although regulation via "nudge" is unlikely to result in significant reform, it does minimize unintended consequences and inefficiencies.

27 Just over a month before the negative "say on pay” vote at Occidental Petroleum, the Wall Street Journal reported that Oxy’s CEO, Ray Irani, was the highest paid executive in its 2009 survey of 200 large companies, with total direct compensation of over \$50 million (Lublin 2010). This figure did not include \$96 million that Irani had gained in 2009 from the exercise of options and vesting of restricted stock. Although Oxy’s recent financial performance has been outstanding, shareholders may have been targeting Irani’s outsized compensation. 
The complexity of executive pay has been a central theme of this chapter. The suggestion for future research is that it more directly address this complexity and the cognitive limitations faced by executives, boards, and even compensation consultants. How do boards and compensation committees manage technically complex compensation matters such as selecting the optimal mix of stock and options? Do compensation consultants understand and effectively mitigate these complexities? How do holdings of stock and options affect the incentives and risk preferences of executives who often have a naïve grasp of the economics of these instruments?

The inherent complexity of executive compensation presents a fundamental challenge for directors. Understanding how the management of complexity translates into pay packages is a key challenge for future compensation research.

\section{References}

Alissa, Walid M. (2009), 'Boards' Response to Shareholders' Dissatisfaction: The Case of Shareholders' Say on Pay in the UK', Working Paper, http://ssrn.com/abstract=1412880.

Anderson, Ronald C. and John M. Bizjak (2003), 'An Empirical Examination of the Role of the CEO and the Compensation Committee in Structuring Executive Pay', Journal of Banking and Finance, 27, 1323-1348.

Baker, George P. and Brian J. Hall (2004), 'CEO Incentives and Firm Size', Journal of Labor Economics, 22, 767-798.

Barris, Linda J. (1992), 'The Overcompensation Problem: A Collective Approach to Controlling Executive Pay’, Indiana Law Journal, 68, 59-100.

Bebchuk, Lucian, Jesse Fried and David Walker (2002), 'Managerial Power and Rent Extraction in the Design of Executive Compensation', University of Chicago Law Review, 69, 751-846.

Bebchuk, Lucian A. and Yaniv Grinstein (2005), 'The Growth of Executive Pay', Oxford Review of Economic Policy, 21, 283-303.

Bebchuk, Lucian A., Yaniv Grinstein, and Urs Peyer, 'Lucky CEOs and Lucky Directors', Working Paper, http://ssrn.com/abstract=1405316.

Bebchuk, Lucian A. and Robert J. Jackson, Jr. (2005), 'Executive Pensions’, Journal of Corporation Law, 30, 823-855.

Bebchuk, Lucian A. and Holger Spamann (2010), 'Regulating Bankers' Pay’, Georgetown Law Journal, 98, 247-287.

Benmelech, Effi, Eugene Kandel, and Pietro Veronesi (2008), 'Stock-Based Compensation and CEO (Dis)Incentives', National Bureau of Economic Research Working Paper No. 13732, http://www.nber.org/papers/w13732.

Bertrand, Marianne and Sendhil Mullainathan (2001), 'Are CEOs Rewarded for Luck? The Ones Without Principles Are', Quarterly Journal of Economics, 116, 901-932.

Bhagat, Sanjai and Roberta Romano (2009), 'Reforming Executive Compensation: Focusing and Committing to the Long-term', Yale Law \& Economics Research Paper No. 374, http://ssrn.com/abstract=1336978.

Bizjak, John M., Michael L. Lemmon, and Lalitha Naveen (2008), 'Does the Use of Peer Groups Contribute to Higher Pay and Less Efficient Compensation?’, Journal of Financial Economics, 90, 152-168.

Blair, Margaret M. and Lynn A. Stout (1999), 'A Team Production Theory of Corporate Law', Virginia Law Review, 85, 248-328.

Brick, Ivan E., Oded Palmon, and John K. Wald (2010), 'Too Much Pay Performance Sensitivity?', Working Paper, http://ssrn.com/abstract=1108522.

Brown, Lawrence D. and Yen-Jung Lee (2007), 'The Impact of SFAS 123R on Changes in OptionBased Compensation', Working Paper, http://ssrn.com/abstract=930818.

Cadman, Brian, Mary Ellen Carter, and Stephen Hillegeist (2010), 'The Incentives of Compensation Consultants and CEO Pay’, Journal of Accounting and Economics, 49, 263-280. 
Carter, Mary Ellen, Luann J. Lynch, and Irem Tuna (2007), 'The Role of Accounting in the Design of CEO Equity Compensation', Accounting Review, 82, 327-357.

Choe, Chongwoo (2001), 'Maturity and Exercise Price of Executive Stock Options', Review of Financial Economics, 10, 227-250.

Choe, Chongwoo (2003), 'Leverage, Volatility and Executive Stock Options', Journal of Corporate Finance, 9, 591-609.

Coffee Jr., John C. (1984), 'Market Failure and the Economic Case for a Mandatory Disclosure System’, Virginia Law Review, 70, 717-753.

Conyon, Martin J. (2010), 'Compensation Consultants and CEO Pay,' Working Paper on file with author.

Conyon, Martin J., Simon I. Peck, and Graham V. Sadler (2009), 'Compensation Consultants and Executive Pay: Evidence from the United States and United Kingdom,' Academy of Management Perspectives, 23(1), 43-55.

Core, John and Wayne R. Guay (1999), 'The Use of Equity Grants to Manage Optimal Equity Incentive Levels', Journal of Accounting and Economics, 28, 151-184.

Core, John E. and Jun Qian (2000), 'Option-like Contracts for Innovation and Production', Working Paper, http://papers.ssrn.com/sol3/papers.cfm?abstract id=207968.

Core, John E., Robert W. Holthausen, and David F. Larcker (1999), 'Corporate Governance, Chief Executive Compensation, and Firm Performance', Journal of Financial Economics, 51, 371-406.

Core, John E., Wayne R. Guay, and David F. Larcker (2003), 'Executive Equity Compensation and Incentives: A Survey', FRBNY Economic Policy Review, 9(1), 27-50.

Core, John E., Wayne R. Guay, and Randall S. Thomas (2005), 'Is U.S. CEO Compensation Inefficient Pay Without Performance?’ Michigan Law Review, 103, 1142-1185.

Dittmann, Ingolf and Maug, Ernst G. (2007), 'Lower Salaries and No Options? On the Optimal Structure of Executive Pay', Journal of Finance, 62, 303-343.

Dittmann, Ingolf and Ko-Chia Yu (2009), 'How Important are Risk-Taking Incentives in Executive Compensation?’, Working Paper, http://ssrn.com/abstract=1176192.

Dodonova, Anna and Yuri Khoroshilov (2006), 'Optimal Incentive Contracts for Loss-Averse Managers: Stock Options versus Restricted Stock Grants', Financial Review, 41, 451-482.

Easterbrook, Frank H. and Daniel R. Fischel (1984), 'Mandatory Disclosure and the Protection of Investors', Virginia Law Review, 70, 669-715.

Elson, Charles (2003), 'What's Wrong with Executive Compensation?', Harvard Business Review, 81(1), 68-77.

Fahlenbrach, Rüdiger and Rene M. Stulz (2009), 'Bank CEO Incentives and the Credit Crisis', Fisher College of Business Working Paper No. 2009-03-13, http://ssrn.com/abstract=1439859.

Feltham, Gerald. A. and Martin Wu (2001), 'Incentive Efficiency of Stock Versus Options', Review of Accounting Studies, 6, 7-28.

Ferri, Fabrizio and David A. Maber (2009), 'Say on Pay Votes and CEO Compensation: Evidence from the UK', Working Paper, http://ssrn.com/abstract=1420394.

Fleischer, Victor (2007), 'Options Backdating, Tax Shelters, and Corporate Culture', Virginia Tax Review, 26, 1031-1064.

Forelle, Charles and James Bandler (2006), 'The Perfect Payday: Some CEOs Reap Millions by Landing Stock Options When They Are Most Valuable', The Wall Street Journal, March 18, A-1.

Frydman, Carola, (2007). 'Rising Through the Ranks: The Evolution of the Market for Corporate Executives, 1936-2003', MIT Sloan School of Management Working Paper, http://mitsloan.mit.edu/finance/pdf/frydman-090208.pdf.

Frydman, Carola and Dirk Jenter (2010), 'CEO Compensation', Rock Center for Corporate Governance at Stanford University Working Paper No. 77, http://ssrn.com/abstract=1582232.

Frydman, Carola and Raven E. Saks (2008), 'Executive Compensation: A New View from a LongTerm Perspective, 1936-2005', National Bureau of Economic Research Working Paper 14145, http://www.nber.org/papers/w14145.

Gabaix, Xavier and Augustin Landier (2006), 'Why Has CEO Pay Increased so Much?', MIT Department of Economics Working Paper No. 06-13, http://ssrn.com/abstract=901826.

Garvey, Gerald T. and Todd T. Milbourn (2006), 'Asymmetric Benchmarking in Compensation: Executives are Rewarded for Good Luck but Not Penalized for Bad', Journal of Financial Economics, 82, 197-225. 
Goldman, Eitan and Steve L. Slezak (2006), 'An Equilibrium Model of Incentive Contracts in the Presence of Information Manipulation', Journal of Financial Economics, 80, 603-626.

Gordon, Jeffrey N. (2009), “'Say on Pay”: Cautionary Notes on the U.K. Experience and the Case for Shareholder Opt-In’, Harvard Journal on Legislation, 46, 323-367.

Grinstein, Yaniv, David Weinbaum, and Nir Yehuda (2010), 'The Economic Consequences of Perk Disclosure', Johnson School Research Paper Series No. 0409, http://ssrn.com/abstract=1108707.

Guay, Wayne R. (1999), 'The Sensitivity of CEO Wealth to Equity Risk: An Analysis of the Magnitude and Determinants', Journal of Financial Economics, 53, $43-71$.

Hall, Brian J. (2003), 'Six Challenges in Designing Equity-Based Pay', Journal of Applied Corporate Finance, 15(3), 21-33.

Hall, Brian J. and Jeffrey B. Liebman (1998), ‘Are CEOs Really Paid Like Bureaucrats?’, Quarterly Journal of Economics, 113, 653-691.

Hall, Brian J. and Jeffrey B. Liebman (2000), ‘The Taxation of Executive Compensation', in James M. Poterba (ed), 14 Tax Policy and the Economy, National Bureau of Economic Research, 1-44.

Hall, Brian J. and Kevin J. Murphy (2000), 'Optimal Exercise Prices for Executive Stock Options', The American Economic Review, 90, 209-214.

Hall, Brian J. and Kevin J. Murphy (2002), 'Stock Options for Undiversified Executives', Journal of Accounting and Economics, 33, 3-42.

Hay Group (2010), 'The Wall Street Journal Survey of CEO Compensation', The Wall Street Journal, March 31, http://graphicsweb.wsj.com/php/CEOPAY10.html.

Heron, Randall A. and Erik Lie (2007), 'Does Backdating Explain the Stock Price Pattern Around Executive Stock Option Grants?', Journal of Financial Economics, 83, 271-95.

Himmelberg, Charles P. and Glenn R. Hubbard (2000), 'Incentive Pay and the Market for CEOs: An Analysis of Pay-for-Performance Sensitivity’, Working Paper, http://ssrn.com/abstract=236089.

Holmström, Bengt R. (1982), 'Moral Hazard in Teams', The Bell Journal of Economics, 13, 324-340.

Holmström, Bengt R. (2005), 'Pay Without Performance and the Managerial Power Hypothesis: A Comment', Journal of Corporation Law, 30, 703-716.

Holmström, Bengt R. and Steven Kaplan (2001), 'Corporate Governance and Merger Activity in the U.S.: Making Sense of the 1980s and 1990s', Journal of Economic Perspectives, 15(2), 121-144.

Holmström, Bengt R. and Steven Kaplan (2003), 'The State of U.S. Corporate Governance: What's Right and What's Wrong?’, Journal of Applied Corporate Finance, 15(3), 8-20.

Jensen, Michael C. and Kevin J. Murphy (1990a), 'CEO Incentives: It's Not How Much You Pay, But How’, Harvard Business Review, 68(3), 138-153.

Jensen, Michael C. and Kevin J. Murphy (1990b), 'Performance Pay and Top-Management Incentives', Journal of Political Economy, 98, 225-264.

Jensen, Michael C., Kevin J. Murphy, and Eric Wruck (2004), 'Remuneration: Where We've Been, How We Got to Here, What Are the Problems, and How to Fix Them', Harvard Negotiations, Organizations, and Markets Unit Research Paper Series No. 05-15, http://ssrn.com/abstract=72338.

Jensen, Michael C. and William H. Meckling (1976), 'Theory of the Firm: Managerial Behavior, Agency Costs and Ownership Structure', Journal of Financial Economics, 3, 305-360.

Knoll, Michael S. (2004), 'The Tax-Efficiency of Stock-Based Compensation', Tax Notes 103, 203-214.

Lambert, Richard A. and David F. Larcker (2004), 'Stock Options, Restricted Stock, and Incentives', Working Paper, http://ssrn.com/abstract=527822.

Larcker, David F., Scott A. Richardson, Andrew Seary, and A. Irem Tuna, 'Back Door Links Between Directors and Executive Compensation', Working Paper, http://ssrn.com/abstract=671063.

Lublin, Joann S. (2010), 'Occidental Chief Tops Pay List', The Wall Street Journal, April 1, B-1.

Mahoney, Paul G. (1995), 'Mandatory Disclosure as a Solution to Agency Problems', University of Chicago Law Review, 62, 1047-1112.

Main, Brian G. M., Charles A. O’Reilly III, and James Wade (1995), 'The CEO, the Board of Directors, and Executive Compensation: Economic and Psychological Perspectives', Industrial and Corporate Change, 11, 293-332.

Millstein Center for Corporate Governance and Performance (2009), Chairing the Board: The Case for Independent Leadership in Corporate North America, Yale School of Management.

Murphy, Kevin J. (1996), 'Reporting Choice and the 1992 Proxy Disclosure Rules', Journal of Accounting, Auditing, and Finance, 11, 497-515. 
Murphy, Kevin J. (1999), 'Executive Compensation', in Orley Ashenfelter (ed), Handbook of Labor Economics, Elsevier, 2485-2563.

Murphy, Kevin J. (2003), 'Stock-Based Pay in New Economy Firms', Journal of Accounting and Economics, 34, 129-147.

Murphy, Kevin J. and Ján Zábojník (2004), ‘CEO Pay and Appointments: A Market-Based Explanation for Recent Trends', The American Economic Review, 94(2), 192-96.

Murphy, Kevin J. and Ján Zábojník (2007), 'Managerial Capital and the Market for CEOs’, Working Paper, http://ssrn.com/abstract=984376.

Murphy, Kevin J. and Tatiana Sandino (2010), 'Executive Pay and "Independent" Compensation Consultants', Journal of Accounting and Economics, 49, 247-262.

O'Reilly III, Charles A. and Brian G. M. Main (2005), 'Setting the CEO's Pay: Economic and Psychological Perspectives', Stanford GSB Research Paper No.1912, http://ssrn.com/abstract=804584.

O’Reilly III, Charles A. and Brian G. M. Main (2007), 'Setting the CEO's Pay: It's More Than Simple Economics', Organizational Dynamics, 1-12.

Palmon, Oded , Sasson Bar-Yosef, Ren-Raw Chen, and Itzhak Venezia (2008), 'Optimal Strike Prices of Stock Options for Effort-Averse Executives’, Journal of Banking and Finance, 32, 229-239.

Peng L, Röell A. (2008), 'Executive Pay and Shareholder Litigation', Review of Finance, 12,141-184.

Polsky, Gregg D. (2007), 'Controlling Executive Compensation Through the Tax Code', Washington and Lee law Review, 64, 877-926.

Posner, Richard A. (2009), 'Are American CEOs Overpaid, and, if so, What if Anything Should be Done About It?’, Duke Law Journal, 58, 1013-1047.

Rappaport, Alfred (1999), 'New Thinking on How to Link Executive Pay with Performance', Harvard Business Review, 77(2), 91-101.

Samuelson, Judith F. and Lynn A. Stout (2009), 'Are Executives Paid Too Much?', The Wall Street Journal, February 25, A-13.

Singh, Ravi (2006), 'Board Independence and the Design of Executive Compensation', Harvard NOM Working Paper No. 673741, http://ssrn.com/abstract=673741.

Sun, Jerry, Steven F. Cahan, and David Emanuel (2009), 'Compensation Committee Governance Quality, Chief Executive Officer Stock Option Grants, and Future Firm Performance', Journal of Banking and Finance, 33, 1507-1519.

Thomas, Randall S. and Kenneth J. Martin (2001), 'Litigating Challenges to Executive Pay: An Exercise in Futility?’, Washington University Law Quarterly, 79, 569-614.

Tian, Yisong S. (2001), 'Optimal Contracting, Incentive Effects and the Valuation of Executive Stock Options', Working Paper, http://ssrn.com/abstract=268738.

Tian, Yisong S. (2004), 'Too Much of a Good Incentive? The Case of Executive Stock Options', Journal of Banking and Finance, 28, 1225-1245.

Tung, Frederick and Xue Wang (2010), 'Bank CEOs, Inside Debt Compensation, and the Financial Crisis', Emory Law and Economics Research Paper No. 10-63, http://ssrn.com/abstract=1570161.

Walker, David I. (2004), 'Is Equity Compensation Tax Advantaged?', Boston University Law Review, $84,695-755$.

Walker, David I. (2007), 'Unpacking Backdating: Economic Analysis and Observations on the Stock Option Scandal', Boston University Law Review, 87, 561-623.

Walker, David I. (2009), 'The Non-Option: Understanding the Dearth of Discounted Employee Stock Options’, Boston University Law Review, 89, 1505-1563.

Walker, David I. (2010a), 'Evolving Executive Equity Compensation and the Limits of Optimal Contracting', Boston University School of Law Working Paper No. 09-34, http://ssrn.com/abstract=1443170.

Walker, David I. (2010b), 'The Challenge of Improving the Long-Term Focus of Executive Pay', Boston College Law Review, 51, 435-472.

Walker, David I. and Victor Fleischer (2009), 'Book/Tax Conformity and Equity Compensation', Tax Law Review, 62, 399-444.

Yale, Ethan (2009), 'Investment Risk is Important When Assessing the Tax Benefit of Deferred Compensation’ Tax Law Review, 62, 377-398. 